\title{
Thương nhớ hồn quê
}

\author{
Khúc Văn Quý
}

December 29, 2020

Preprint DOI: https://osf.io/vsxpb

Tình quê rộng lắm đơn sơ lắm Một chén trà con cũng độm đà

Canh Đay ${ }^{1}$, hương Mướp $p^{2}$ mùa năm trước Có phải xa rồi mới nhớ quê

*

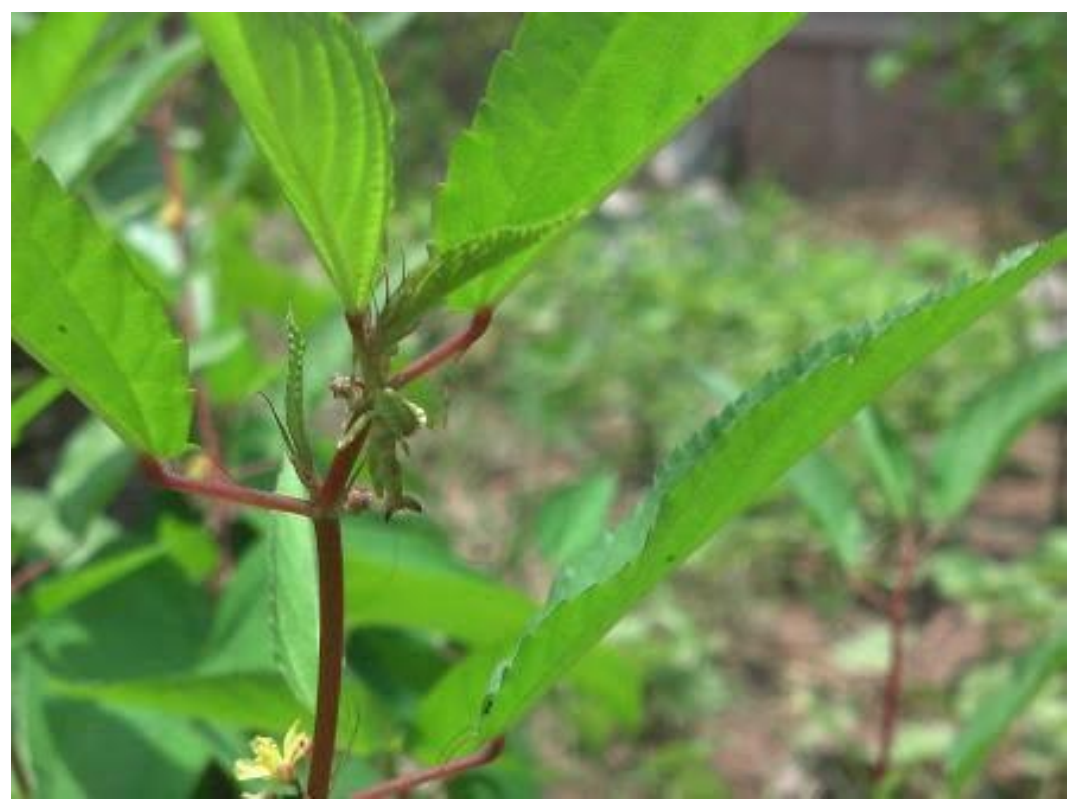

Rau Day (C2020 photo courtesy: Quan-Hoang Vuong

Đã dặn lòng mình giữ lặng đi thôi

Sao vẫn vấn vương vào tình quê thế nhi Những rung động, ưu tư, trở trăn, suy nghĩ Lại cứ ùa về 'thương nhớ hồn quê'

${ }^{1}$ Rau Đay thường dùng nấu món Canh Cua, món này ở quê Bắc Bộ còn gọi là món 'Canh Cua rau Đay'

${ }^{2}$ Mướp ở đây chỉ quả 'Mướp Hương', cũng thường cùng với rau Đay để nấu món canh mướp, rất ngon 